\title{
Assessment of knowledge about nosocomial infection among Cukurova University Vocational School of Health Services Students
}

\section{Çukurova Üniversitesi Sağlık Hizmetleri Meslek Yüksekokulu öğrencilerinde nozokomiyal enfeksiyon bilgi düzeylerinin değerlendirilmesi}

\author{
Pınar ETiZ ${ }^{1}$, Sedefgül YüZBAŞIOĞLU-ARIYÜREK ${ }^{1}$
}

\section{ABSTRACT}

Objective: Nosocomial infection is an infection if it becomes positive 48 hours or more after admission to the hospital or within 30 days of discharge. Nosocomial infection in healthcare facilities is a major public health problem in most developing countries. Basic infection control measures in any healthcare students setup can reduce the rates of healthcare-associated infections. Thus, it is important to identify the level of their knowledge, by correcting their deficiencies. The current study aimed to evaluate the level of knowledge regarding nosocomial infection among healthcare students.

Methods: A descriptive study was conducted among 565 healthcare students. A structured selfadministered questionnaire was used to collect data. The questionnaire included two parts: demographic characteristic, level of knowledge among the healthcare students. Data was analyzed using IBM SPSS Statistics version 22 and the associations were tested with Kruskal Wallis and Mann Whitney $U$ test with a p-value of $<0.05$.

Results: Five hundred and sixty-five students were included in the study. Students mean age was $20,99 \pm 2,64$

\section{ÖZET}

Amaç: Nozokomiyal enfeksiyonlar, genellikle hasta hastaneye yattıktan 48 saat sonra daha veya sonrasında gelișen, ayrica taburcu olduktan sonra 30 gün içinde orataya çıkabilen enfeksiyonlardır. Gelișmekte olan ülkelerin çoğunda, sağlık kurumlarında nozokomiyal enfeksiyon önemli bir halk sağlığı sorunudur. Sağlık hizmetlerinde öğrenim gören öğrencilerin enfeksiyon kontrol önlemlerini bilmeleri sağıı hizmetleri ile ilișkili enfeksiyon oranlarını önemli ölçüde düşürebilir. Bu nedenle, öğrencilerin bilgi seviyesini belirleyerek eksikleri tamamlamak oldukça önemlidir. Bu çalıșmada; sağlık hizmetlerinde öğrenim gören öğrencilerin nozokomiyal enfeksiyonlara ilișkin bilgi düzeylerinin belirlenmesi amaçlanmıștır.

Yöntem: Çalıșma 565 sağlık hizmetleri öğrencisi üzerinde tanımlayıcı olarak yapılmıștır. Veriler öğrencilerin gözlem altında doldurdukları anket aracılığı ile toplanmıștır. Anket öğrencilerin demografik özelliklerini ve bilgi düzeylerini belirlemeye yönelik olarak iki bölümden olușmaktadır. Çalıșmada elde edilen bulgular değerlendirilirken istatistiksel analizler için IBM SPSS Statistics 22 programı kullanılmıștır. Niceliksel verilerin ikiden fazla grup arası değerlendirmelerinde Kruskal Wallis testi, farklılığa neden olan grubun

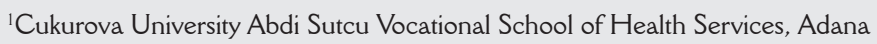

İletişim / Corresponding Author : Pınar ETiz

Çukurova Üniversitesi Abdi Sütcü Sağlık Hizmetleri Meslek Yüksekokulu 01330 Adana - Türkiye

Tel : +905302024486 E-posta /E-mail : pinaretiz@yahoo.com

Geliş Tarihi / Received : 01.10.2018

Kabul Tarihi / Accepted : 09.08.2019

DOI ID : 10.5505/TurkHijyen.2019.69335

Etiz P, Yüzbasıoğlu-Arıyürek S. Assessment of knowledge about nosocomial infection among Cukurova University Vocational School of Health Services Students. Turk Hij Den Biyol Derg, 2020; 77(1): 69-78 
(range, 17-37 years). The majority of the students (58.1\%) were $\leq 20$ year-old, $(69.7 \%)$ were female, $(57.7 \%)$ were attended occupational training program, $11.1 \%$ of them have working experience. The percentage of students' knowledge of hospital infections is between 10 and 100 , with a mean knowledge level of $73.0 \pm 17.23$ and a median of 80 .

Conclusion: The overall knowledge level for infection control indicated that instruction was effective; however, knowledge levels were different. A periodically check of heatlhcare students' knowledge would be advisable in order to fill any gaps, improve training, reduce nosocomial infections and increase prevention measures compliance. For this purpose continuing education programs and seminars should be arranged on regular basis.

Key Words: Nosocomial infection, health service students, knowledge level, questionnaire tespitinde ise Mann Whitney U post hoc testi kullanılmıștır. Anlamlılık p<0,05 düzeyinde değerlendirilmiștir.

Bulgular: Çalıșmaya 565 öğrenci dahil edilmiștir. Öğrencilerin yaşları 17 ile $37 \mathrm{yll}$ arasında değișmekte olup ortalaması $20,99 \pm 2,64$ 'dür. Öğrencilerin büyük çoğunluğu $(\% 58,1) 20$ yașın altındaydı, \%69,7'si kadındı ve \% 57,7'si daha önce mesleki eğitim programına katılmıștı, \%11,1'inin de çalıșma deneyimi vardı. Öğrencilerin hastane enfeksiyonlan bilgi yüzdeleri 10 ile 100 arasında değișmekte olup, ortalaması 73,0 $\pm 17,23$ ve medyanı 80 'dir.

Sonuç: Enfeksiyon kontrolü için öğrencilerin genel bilgi seviyesi öğretimin etkili olduğunu gösterse de, bilgi düzeyleri arasında farklılıklar belirlenmiștir. Öğrencilerin bilgi seviyeleri arasındaki boșluğu doldurmak, eğitimi geliștirmek, nozokomiyal enfeksiyonları azaltmak ve enfeksiyonları önlemeye yönelik uyumu arttırmak için periyodik olarak bilgi seviyeleri belirlenmelidir. Bu amaçla düzenli olarak sürekli eğitim programları ve seminerler düzenlenmelidir.

Anahtar Kelimeler: Nozokomiyal enfeksiyon, sağlık hizmetleri öğrencileri, bilgi düzeyi, anket

\section{INTRODUCTION}

Nosocomial infections also regarded as hospital acquired infections (HAls) are infections acquired in hospitals by patients who are admitted for a reason other than that infection and first appear $48 \mathrm{~h}$ or more after hospital admission or with in 30 day after discharge (1).

Nosocomial infections happen worldwide and impress both developed and developing countries. Infections acquired in health care settings are among the major causes of mortality and increased morbidity among hospitalized patients(2). Developing countries were stated to have up to 20 times the risk of contracting a nosocomial infection compared with improved countries(3,4). A prevalent survey in 2002 conducted under the auspices of the World Health
Organization (WHO) in 55 hospitals of 14 countries representing four WHO regions (Europe, Eastern Mediterranean, South-East Asia and Western Pasific) indicated an average of $8.7 \%$ of hospital patients had nosocomial infections (5).

Although infections mostly originate from patients, health care workers also can be a main source of vectors for pathogenic agents (6). These diseases are usually caused by bacteria or viruses particularly hepatitis $B$ and $C$ viruses, human immunodeficiency virus, vancomycin-resistant enterococci (VRE), methicillin resistant Staphylococcus aureus (MRSA), avian or pandemic influenza viruses (7). There are various different exposure routes: through injury (cut, prick), through contact with the skin or mucous 
membranes, through inhalation or through ingestion. There is an increasing number of healthcare workers both in developed and developing countries who have been exposed to pathogens while caring of patients (8). Prevention of healthcare-associated infections is the duty of all healthcare workers (9). Common pathogens may easily be transmitted through healthcare workers' hands, equipment, supplies and unhygienic practices (10). So, all healthcare workers should routinely use appropriate barrier precautions to prevent skin and mucous membrane exposure during contact with any patient's blood or body fluids that require universal precautions $(11,12)$. Strict adherence by healthcare workers to standard infection control precautions may prevent a percentage of these risks.

Healthcare workers play a significant role in spreading the infection and they are regarded as key members of managing and controlling the hospital infections; thus, healthcare workers must have correct, up-to date and appropriate scientific information regarding varieties of hospital infections, their effects on afflicting patients, and increased hospital costs, recognition of people at risk and also the criteria to prevent and control. On the other hand, healthcare workers knowledge and practice regarding sanitary conditions play a vital role to guarantee the individual and ultimately social health, increased level of healthcare workers knowledge positively affects their performance (13).

Also healthcare students play a serious role in spreading nosocomial infections. Healthcare students are exposed early to the hospitals and to activities which increase their risk of acquiring and transmitting infections (8). To protect healthcare students from percutaneous injuries and to prevent nosocomial infection, students should have adequate knowledge before their initial training period at a hospital (14). Moreover, these individuals represent potential future healthcare professional or leaders in the fight against nosocomial infections, so it is significant that they know how to control the nosocomial infections appropriately.

The aim of this study was to determine the level of knowledge regarding prevention of nosocomial infections among heathcare students.

\section{MATERIAL and METHOD}

\section{Study Design}

This research was designed as a descriptive study which evaluated knowledge of general principles of infection prevention and control of students in the public-sector university in Adana, Turkey. The study consisted of students attending one of the six 2-year programs (Anesthesia, Medical Documentation and Secretariat, Medical Imaging Techniques, Medical Laboratory Techniques, First and Emergency Aid, Oral and Dental Health, Dental Prosthesis Techniques, Physiotherapy, Aged (are) at the Cukurova University Vocational School of Health Services during the 20162017 academic year.

\section{Ethical Considerations}

Prior to the study, all participants were informed about the purposes and methods of the study. All potential respondents were clearly advised that participation in thestudy was voluntaryand anonymous, so they could refuse to participate or withdraw from the study at any stage. All the participants completed and returned the questionnaire, giving a response rate of $100 \%$. Ethical approval for this research was obtained from the ethical review committee of Cukurova University Medical Faculty in accordance with the Helsinki Recommendations.

\section{Questionnaire Design}

Data was collected using a structured selfadministered questionnaire, which had been designed after an extensive literature search. The questionnaire consisting of 18 questions in descriptive type was divided into two main components. The first part contained parameters for determination of sociodemographic characteristics such as (age, 
gender, year in the programme, employment status, participation record in the infection control education during the past years), the second part contained ten multiple-choice questions to evaluate their knowledge level about the prevention of nosocomial infection (immunization, hand hygiene, rational antibiotic use, standard precautions). The questionnaires were handout to the students in the classroom and collected at the end of the period. The participants were requested to respond to questions according to their own awareness about the subject.

Students' knowledge levels were measured by a multiple-choice questions questionnaire prepared by experts in their field. The number of correct answers that students give to all questions is divided by the total number of questions and a variable is determined that determines the level of knowledge in terms of percentage. Therefore, information levels range from $0 \%$ to $100 \%$.

\section{Data Analysis}

All the responses were collected and analyzed statistically using IBM SPSS Statistics version 22. The normal distribution fitness of the variables was determined by the Kolmogorov Smirnov test, and the variables were not fit to normal distribution. Descriptive statistical methods (min-max, mean, standard deviation, median, frequency) as well as Mann-Whitney $U$ test were used for the two groups of quantitative data. The Kruskal Wallis test was used for more than two intergroup evaluations of the quantitative data, and the Mann Whitney $U$ with Bonferroni corection post-hoc test was used to determine the group causing the difference. A value of $p<0.05$ was considered statistically significant.

\section{RESULTS}

Five hundred and sixty-five students responded to the distributed questionnaires (100\%). Students mean age was 20.99 \pm 2.64 (range, 17-37 years), from whom 394 (69.7\%) were female and 171 (30.3\%) were male. Table 1 showed demographic characteristics of the studied sample. The majority of them were $\leq 20$ year old (58.1\%) and female (69.7\%). Responses to questions about hospital-acquired infections and the cleaning process were summarized in Table 2. The percentage of hospital infections information among students ranged from 10 to 100, with an average of $73.00 \pm 17.23$ and a median of 80 . Students above 20 years had a statistically significant higher level of knowledge of nosocomial infections than from those under 20 years of age $(p<0.01)$. It was found that women had a statistically significant higher level of knowledge of nosocomial infections than men $(p<0.01)$ (Table 3).

Also the group who attended any occupational training program regarding infection control had the high knowledge of nosocomial infections than the non-attending group. There was a statistically significant relationship between knowledge and occupational training program $(p<0.01)$. There was a statistically significant difference for those who had previously been educated about hospital infections information among the places where they had been trained $(p=0.025)$. As a result of post hoc binary comparisons, it was found that the knowledge level percentage of hospital-acquired infections in schooleducated subjects was significantly higher than those educated in other places and the ministry of health education. Knowledge level of the students working in the clinics was found statistically significantly higher than that of the students with non-working experince $(p<0.01)$ (Table 3$)$.

Additionally there was a statistically significant relationship between knowledge level and teaching program $(p<0.01)$. As a result of post-hoc comparisons to determined which program originated the difference, the knowledge level of hospital infection in those teaching in the medical documentation and secretarial program students was significantly lower than those in the oral-dental health and aged care program students $(p<0.0014) \quad$ (The corresponding 
Table 1. Socio-demographic characteristics of respondents $(n=565)$

Min-Max Mean \pm SD (Median)

\begin{tabular}{|c|c|c|c|}
\hline Age (year) & & $17-37$ & $20.99 \pm 2.64(20)$ \\
\hline & & n & $\%$ \\
\hline \multirow{2}{*}{ Age Group } & $\leq 20$ years & 328 & 58.1 \\
\hline & $>20$ years & 237 & 41.9 \\
\hline \multirow{2}{*}{ Sex } & Female & 394 & 69.7 \\
\hline & Male & 171 & 30.3 \\
\hline \multirow{9}{*}{ Teaching Program } & Medical Laboratory Techniques & 127 & 22.5 \\
\hline & Medical Imaging Techniques & 105 & 18.6 \\
\hline & Physiotherapy & 73 & 12.9 \\
\hline & Aged Care & 20 & 3.5 \\
\hline & Dental Prosthesis Techniques & 12 & 2.1 \\
\hline & Medical Documentation and Secretariat & 35 & 6.2 \\
\hline & Anesthesia & 65 & 11.5 \\
\hline & Oral and Dental Health & 35 & 6.2 \\
\hline & First and Emergency Aid & 93 & 16.5 \\
\hline \multirow{2}{*}{ Class } & $1^{\text {st }}$ year & 249 & 44.1 \\
\hline & $2^{\text {nd }}$ year & 316 & 55.9 \\
\hline \multirow{2}{*}{$\begin{array}{l}\text { Participated in nosocomial } \\
\text { infections training in the past }\end{array}$} & Yes & 326 & 57.7 \\
\hline & No & 239 & 42.3 \\
\hline \multirow{3}{*}{$\begin{array}{l}\text { If yes, where did you participated } \\
\text { in nosocomial infections training } \\
(n=326)\end{array}$} & Lesson & 256 & 78.5 \\
\hline & Ministry of Health & 27 & 8.3 \\
\hline & Other & 40 & 12.3 \\
\hline \multirow{2}{*}{$\begin{array}{l}\text { Work experience in any health } \\
\text { institution }\end{array}$} & Yes & 62 & 11.0 \\
\hline & No & 503 & 89.0 \\
\hline
\end{tabular}

threshold $p$ value was $0.05 / 36=0.0014)$. Evaluation of hospital infection knowledge levels according to socio-demographic characteristics of students were summeriazed in Table 3.

\section{DISCUSSION}

The study described and compared knowledge about nosocomial infection among 565 healthcare students. There are various studies which reveal the 
Table 2. Frequent response to questions by study population $(n=565)$

\begin{tabular}{|c|c|c|c|}
\hline & & $\mathrm{n}$ & $\%$ \\
\hline \multirow{3}{*}{$\begin{array}{l}\text { Is hepatitis B vaccination important } \\
\text { in the prevention of hospital } \\
\text { infections? }\end{array}$} & Yes* & 513 & 90.8 \\
\hline & No & 6 & 1.1 \\
\hline & Unknown & 46 & 8.1 \\
\hline \multirow{3}{*}{$\begin{array}{l}\text { What is the role of rational } \\
\text { antibiotic use in preventing } \\
\text { nosocomial infections? }\end{array}$} & Significant* & 425 & 75.2 \\
\hline & Insignificant & 19 & 3.4 \\
\hline & Unknown & 121 & 21.4 \\
\hline \multirow{3}{*}{$\begin{array}{l}\text { Which of the following measures } \\
\text { is the most important role in the } \\
\text { prevention of hospital infection and } \\
\text { must be implemented? }\end{array}$} & wearing gloves & 152 & 26.9 \\
\hline & Hand washing* & 354 & 62.7 \\
\hline & Isolation & 59 & 10.4 \\
\hline \multirow{4}{*}{$\begin{array}{l}\text { How should it be dried after the } \\
\text { hands are washed? }\end{array}$} & With disposable towel ${ }^{*}$ & 536 & 94.9 \\
\hline & With gauze patch & 12 & 2.1 \\
\hline & With warm hair & 16 & 2.8 \\
\hline & With paper & 1 & 0.2 \\
\hline \multirow{4}{*}{$\begin{array}{l}\text { Which one is true for hospital } \\
\text { infections? }\end{array}$} & $\begin{array}{l}\text { Infections acquired in hospitals by patients who are admitted for } \\
\text { a reason other than that infection first appear } 48 \mathrm{~h} \text { or more after } \\
\text { hospital admission or with in } 30 \text { day after discharge.* }\end{array}$ & 427 & 75.6 \\
\hline & $\begin{array}{l}\text { They are in the period of incubation at the time of application } \\
\text { and infections that developed } 48-72 \text { hours after admission to the } \\
\text { hospital. }\end{array}$ & 90 & 15.6 \\
\hline & $\begin{array}{l}\text { Infections that develop after } 48 \text { to } 72 \text { hours from one patient to } \\
\text { another. }\end{array}$ & 38 & 6.7 \\
\hline & Nosocomial infections occur within the first 48 hours of birth & 10 & 1.8 \\
\hline \multirow{3}{*}{$\begin{array}{l}\text { Hospital infections can be reduced } \\
\text { by } 30-40 \% \text { with full compliance of } \\
\text { handwashing and hand hygiene of } \\
\text { health personnel. }\end{array}$} & Yes* & 536 & 94.9 \\
\hline & No & 3 & 0.5 \\
\hline & Unknown & 26 & 4.6 \\
\hline \multirow{3}{*}{$\begin{array}{l}\text { In hospital infections the permanent } \\
\text { skin flora of health personnel is } \\
\text { more important than temporary } \\
\text { flora. }\end{array}$} & Yes* & 258 & 45.7 \\
\hline & No & 46 & 8.1 \\
\hline & Unknown & 261 & 46.2 \\
\hline \multirow{4}{*}{$\begin{array}{l}\text { Which of the following is not a } \\
\text { member of the Hospital Infection } \\
\text { Control Committee? }\end{array}$} & Clinical microbiologist & 84 & 14.9 \\
\hline & Laboratory technician* & 437 & 77.3 \\
\hline & Infectious disease specialist & 14 & 2.5 \\
\hline & Infection control nurse & 30 & 5.3 \\
\hline \multirow{4}{*}{$\begin{array}{l}\text { In which of the following situations } \\
\text { should sterile gloves be worn? }\end{array}$} & Endotracheal aspiration* & 334 & 59.1 \\
\hline & Medical dressing & 167 & 29.6 \\
\hline & Vessel path opening & 36 & 6.4 \\
\hline & Bloodletting & 28 & 5.0 \\
\hline \multirow{4}{*}{$\begin{array}{l}\text { Which one of the following is true } \\
\text { about a patient who has airway } \\
\text { isolation? }\end{array}$} & The room of the door can be left open & 38 & 6.7 \\
\hline & Special ventilation is required for the patient room* & 308 & 54.5 \\
\hline & The green clover leaf card should be hung on the door & 71 & 12.6 \\
\hline & Surgical mask should be worn when entering the room & 148 & 26.2 \\
\hline
\end{tabular}

Correct Answer: * 
Table 3. Evaluation of hospital infection knowledge levels according to socio-demographic characteristics of students ( $\mathrm{n}=565$ )

\begin{tabular}{|c|c|c|c|}
\hline General Characteristics & Median (Min-Max) & Knowledge Level (\%) & $\mathrm{p}$ \\
\hline \multirow{2}{*}{ Age Group } & $\leq 20$ & $70(10-100)$ & \multirow{2}{*}{${ }^{1} 0.001$ ** } \\
\hline & $>20$ & $80(10-100)$ & \\
\hline \multirow{2}{*}{ Sex } & Female & $80(10-100)$ & \multirow{2}{*}{${ }^{1} 0.001^{* *}$} \\
\hline & Male & $70(10-100)$ & \\
\hline \multirow{9}{*}{ Teaching Program } & Medical Laboratory Techniques & $80(20-100)$ & \multirow{9}{*}{${ }^{2} 0.008^{* *}$} \\
\hline & Medical Imaging Techniques & $80(30-100)$ & \\
\hline & Physiotherapy & $80(30-100)$ & \\
\hline & Aged Care & $80(40-100)$ & \\
\hline & Dental Prosthesis Techniques & $50(10-90)$ & \\
\hline & Medical Doc. and Secretariat & $70(30-100)$ & \\
\hline & Anesthesia & $80(70-100)$ & \\
\hline & Oral and Dental Health & $70(40-100)$ & \\
\hline & First and Emergency Aid & $75(50-100)$ & \\
\hline \multirow{2}{*}{ Class } & $1^{\text {st }}$ year & $70(10-100)$ & \multirow{2}{*}{${ }^{1} 0.001^{* *}$} \\
\hline & $2^{\text {nd }}$ year & $80(30-100)$ & \\
\hline \multirow{2}{*}{$\begin{array}{l}\text { Participated in nosocomial } \\
\text { infections training in the past }\end{array}$} & Yes & $80(30-100)$ & \multirow{2}{*}{${ }^{1} 0.001$ ** } \\
\hline & No & $70(10-100)$ & \\
\hline \multirow{3}{*}{$\begin{array}{l}\text { If yes, where did you } \\
\text { participated in nosocomial } \\
\text { infections training }(n=326)\end{array}$} & Lesson & $80(30-100)$ & \multirow{3}{*}{${ }^{2} 0.025^{*}$} \\
\hline & Ministry of Health & $70(40-100)$ & \\
\hline & Other & $80(40-90)$ & \\
\hline \multirow{2}{*}{$\begin{array}{l}\text { Work experience in any health } \\
\text { institution }\end{array}$} & Yes & $80(40-100)$ & \multirow{2}{*}{${ }^{1} 0.001 * *$} \\
\hline & No & $80(10-100)$ & \\
\hline
\end{tabular}

importance of infection control practice in other professions. Nurses and physicians knowledge of standard and isolation precautions have been stated to be insufficient. Nevertheless, this questionnaire recorded only student responses. Few studies have reported on healthcare student's knowledge of nosocomial infections $(9,15-17)$. In one research, $27 \%$ of participating healthcare students reported insufficient underlines on teaching about infection control in their training program, whilst $50 \%$ expressed a desire for more emphasis on isolation procedures throughout their training program (18).
In our study, it was detected that $57.7 \%$ of the students had already been educated about nosocomial infections and $78.5 \%$ of them had received formal teaching throughout the curriculum. Formal teaching during the curriculum was indicated to be the main source of information influencing students' knowledge about preventive measures for nosocomial infections. This proportion was relatively high compared with that obtained in a study by Bell et al, (3) in which $36 \%$ of sampled students citing formal training in curriculum as their main source of information. Teaching infection control to healthcare students 
is a challenge both with respect to developing a cohesive program and encouraging students to adopt correct attitudes early in their careers (14). Sax et al. (19) reported that lack of knowledge is the major reason for nonadherence to standard and isolation precautions. Nobile et al. (20) stated that a positive attitude about hand disinfection was higher among healthcare students with a higher level of knowledge. However, educational background is one of the factors influencing compliance with good practices; indeed, education works synergistically with other factors: behavior and practice (14). Studies demonstrated that formal training program in curriculum of standard precautions can quickly develop students' knowledge of infection control in a short period of time.

Based on the results of the present study, $41.9 \%$ of the participating students were 20 years old and above. This result is similar to the result reported in previous studies carried out by Alrubaiee et al. (21) in Yemen, Ginny Kaushal et al. (22) in India. Nevertheless, our result is consistent with this previous study concerning the gender as Kaushal et al.(22), Brosio et al. (7) and Wasswa et al. (23) stated that most of the study participants were females. We think that women are more careful and selfless in preventing infections.

According to the results of this study, only a small percentage of students (11\%) have experience working in the health institution (Table 1). Concerning to the students' work experience, this study result indicated significant relationship between the students' work experience and their knowledge of nosocomial infection, this might relate to received training about nosocomial infection from in-house programs and practices within the hospital. This result disagreed with the results obtained from a previous study done in Yemen showed that there is an insignificant association between the knowledge and work experince (11).

Much as knowledge of nosocomial infection is significant to all health workers, our study appears to show that there is higher knowledge among oral and dental health and aged care students compared to medical documentation and secretariat students. First and amergency aid students showed weaknesses in knowledge level of nosocomial infections. It may be that the students don't care much about this topic. Whereas adequate infection and prevention control must be practiced at all times when administering first aid. Ojulong et al. (8) found that medical students appear to show that higher knowledge compared to nursing/radiography students. We think that the occupational practices of the students influence their knowledge levels. Learning practices are indispensable for improving student knowledge of nosocomial infection and the prevention of infection transmission (14,24-27). Teaching infection control to all healthcare students is a challenge both with respect to developing a cohesive program and encouraging students to adopt correct attitudes early in their careers (14).

In conlusion, knowledge and attitudes are believed to play a significant role in the acquisition of infection control practices, and all healthcare students' education has been recommended as an important strategy to develop compliance and to reduce nosocomial infection rates $(8,9)$. We determined that knowledge about nosocomial infection of its significance among healthcare students was high from previously published studies on this topic. In general, studies include doctors, nurses and radiologists, while our study includes students who will serve in all areas of the healthcare industry (8).

Based on the findings of this study, we suggest that vocational school of health services should introduce the module of nosocomial infection at the earliest opportunity to healthcare students at the school. Teaching methods should be developed to increase knowledge of infection control. Also the education of healthcare students during the years of clinical practice is very important. 


\section{REFERENCES}

1. Irene Ocran I, Tagoe DNA. Knowledge and attitude of healthcare workers and patients on healthcare associated infections in a regional hospital in Ghana. Asian Pac J Trop Dis, 2014; 4 (2): 135-9.

2. Sorte D. Nurses knowledge related to prevention of nosocomial infection. Int J Sci Res, 2015; 4 (7): 38-40.

3. Bello Al, Asiedu EN, Adegoke BOA, Quartey JNA, Appiah-Kubi KO, Owusu-Ansah B. Nosocomial infections: knowledge and source of information among clinical health care students in Ghana. Int J Gen Med, 2011; 4, 571-4.

4. World Health Organization. 10 facts on patient safety. Available from: http://www.who.int/ feature/factsfile/patientsafety/en/, (Dated: October 8, 2018).

5. World Health Organization. Global Alert and Response. Geneva: World Health Organization; 2002. [Online] Available from: http://www.who. int/csr/resources/publications/WHO_CDS_CSR EPH_2002_12/en/, (Dated: October 8, 2018).

6. Jayasinghe RD, Weerakoon BS. Prevention of nosocomial infections and standard precautions: knowledge and practice among radiographers in Sri Lanka. J Med Allied Sci, 2014; 4 (1): 9-16.

7. Brosıo F, Kuhdarı P, Stefanatı A, Sulcaj N, Lupı S, Guidi E, et al. Knowledge and behaviour of nursing students on the prevention of healthcare associated infections. J Prev Med Hyg, 2017; 58: E99-E104.

8. Ojulong J, Mitonga $\mathrm{KH}$, lipinge $\mathrm{SN}$. Knowledge and attitudes of infection prevention and control among health sciences students at University of Namibia. Afr Health Sci, 2013; 13 (4): 1071-8.

9. Masavkar SP, Naikwadi AM. Knowledge, attitude and practice regarding nosocomial infections among general health practitioners and medical college students. Sch J App Med Sci, 2016; 4 (5): 1852-6.

10. Gichuhi AW, Kamau SM, Nyangena E, Otieno- Ayayo ZN. Health care workers adherence to infection prevention practices and control measures: A case of a level four district hospital in Kenya. Am J Nurs Sci, 2015; 4 (2): 39-44.
11. Gawad A. Assessment of Knowledge about Standard Precautions and Nosocomial Infection among Nurses Working in Hospitals of Sana'a City, Yemen. Int J Caring Sci, 2017; 10 (1): 169-175.

12. Kaur R, Kaur B, Walia I. Knowledge, attitude and practice regarding universal precautions among nursing Students. Nurs Midwifery Res J, 2008; 4 (4): 115-127.

13. Kalantarzadeh M, Mohammadnejad E, Ehsani SR; Tamizi Z. Knowledge and practice of nurses about the control and prevention of nosocomial infections in emergency departments. Arch Clin Infect Dis, 2014; 9 (4): e18278.

14. Tavolacci MP, Ladner J, Bailly L, Merle V, Pitrou I, Czernichow P. Prevention of nosocomial infection and standard precautions: knowledge and source of information among healthcare students. Infect Control Hosp Epidemiol, 2008; 29: 642-7.

15. Askarian M, Honarvr B, Tabatabaee HR, Assadian 0 . Knowledge, practice and attitude towards standard isola-tion precaution in Iranian medical students. J Hosp Infect, 2004; 58: 292-6.

16. Mann CM, Wood A. How much do medical students know about infection control? J Hosp Infect, 2006; 64: 366-70.

17. Koenig S, Chu J. Senior medical students knowledge of universal precautions. Acad Med, 1993; 68: 3724.

18. Suchitra JB, Lakshmidevi N. Impact of education on know-ledge, attitudes and practices among various categories of health care workers on nosocomial infections. Indian J Med Microbiol, 2007; 25: 181-7.

19. Sax H, Perneger T, Hugonnet S, Herrault P, Chraïti $M N$, Pittet D. Knowledge of standard and isolation precautions in a large teaching hospital. Infect Control Hosp Epidemiol, 2005; 26: 298-304.

20. Nobile C, Montuori P, Diaco E, Villari P. Healthcare personnel and hand decontamination in intensive care units: knowledge, attitudes and behaviour in Italy. J Hosp Infect, 2002; 51: 226-32. 
21. Alrubaiee G, Baharom A, Shahar HK, Daud SM, Basaleem HO. Knowledge and practices of nurses regarding nosocomial infection control measures in private hospitals in Sana'a City, Yemen. Saf Health, 2017; (3) 16: 1-6.

22. Kaushal G, Doke P, Shah A, Verma V. An Analysis of Knowledge, Attitude and Practices regarding Standard Precautions of Infection Control and Impact of Knowledge and Attitude of ICU nurses on self-reported Practices of Infection Control. Int J of Res Foundation Hosp and Healthc Adm, 2015; (3) 2: 79-85.

23. Wasswa P, Nalwadda CK, Buregyeya E, Gitta SN, Anguzu P, Nuwaha F. Implementation of infection control in health facilities in Arua district, Uganda: a cross-sectional study. BMC Infect Dis, 2015; 15: 268.
24. Kim KM, Kim MA, Chung YS, Kim NC. Knowledge and performance of the universal precautions by nursing and medical students in Korea. Am J Infect Control, 2001; 29: 295-300.

25. Calabro K, Weltge A, Parnell S, Kouzekanani K, Ramirez E. Intervention for medical students: effective infection control. Am J Infect Control, 1998; 26: 431-6.

26. Jeffe DB, Mutha S, Kim LE, Evanoff BA, Fraser VJ. Evaluation of a preclinical, educational and skillstraining program to improve students' use of blood and body fluid precautions: one year follow-up. Preventive Med, 1999; 29: 365-73.

27. Colombo C, Giger H, Grote J, Deplazes C, Pletscher W, Luthi R, et al. Impact of teaching interventions on nurse compliance with hand disinfection. J Hosp Infect, 2002; 51: 69-72. 